\title{
Linkage Behavior and Practices of Agencies in the Agricultural Innovation Transfer Sub System in Southeastern Nigeria: Issues for Agricultural Extension policy
}

\author{
Dimelu, M.U and A.C. Anyanwu \\ Department of Agricultural Extension \\ University of Nigeria, Nsukka \\ mabeldimelu@yahoo.com
}

\begin{abstract}
The study examined the linkage behaviour and practices of agencies in the agricultural innovation transfer sub system in Southeastern Nigeria. A total sample size of 210 respondents purposively selected from ADPs(60), LGs(60), profit NGOs(60), non- profit NGOs(30) were used. Data were collected by the use of questionnaires; and analyzed using percentage, mean scores, and factor analysis. The study revealed poor linkage dynamics among the agencies. Majority (72.2\%) ADPS of the respondents indicated strong linkages with research institutes, but linkages with agencies in the transfer sub-system were either weak or not in existence. The LGs as well as profit NGOs had either weak or no linkage with most agencies in both innovation generation and transfer sub- systems. Non-profit NGOs(50.0\%) reported somewhat strong linkages with research institutes; while (61.5\%,65.5\%and 50.0\%) indicated that linkages with universities of agriculture, colleges of agriculture and para-veterinary firms were not in existent, respectively. The major linkage mechanisms that existed among the agencies were use of bulletin, annual reports, and magazine. Factors constraining linkages among the agencies were policy related, organizational, attitude -related, and motivational. The study concludes that operational and structural mechanisms should be put in place to facilitate strong and effective linkages for efficiency of resource use and cost effectiveness through synergies and complementarities of efforts. Government should entrench linkage mandate in policies establishing research-extension system to encourage and facilitate public-public and public-private linkages in the sub-system. Existing institutional framework for linkages between research and extension system should be re-visited to evolve more dynamic arrangements and to create mechanism for increase participation of private agencies. Also policy makers should invest on orientation and building linkage leadership among administrators and extension practitioners to stimulate innovation culture.
\end{abstract}




\section{INTRODUCTION}

Innovation is the process by which firms master and implements the design and production of goods and services that are new to them, irrespective of whether they are new to their competitors, countries or the world (CTA 2006). It is increasingly recognized as requiring the convergence of many sources of knowledge and skill usually in the form of a network (Nigel et.al 2001). According to Watt et al (2003) innovations are introduced by individual oorganizations, be they firms or research institutions by the complexity of innovation processes. Lundvall (1992) pointed out that complexity refers to the characteristics of system in which many elements interact with each other to create cumulative and unpredictable outcome.

A system of innovation consists of major social actors/organizations that affect the revealing, acknowledgment, generation and diffusion of technical and institutional knowledge over time (Clark et al, 2003; Ekboir 2002 and. Hall et al, 2001). Tugrul et al. (2001) further added that an innovation system also includes the interactive learning that occurs when organisations engage in generation, adaptation, and use of new knowlegde and the institution (rules and norms)that govrrn how the interaction and processesoccur. On the other hand, 'innovation' takes place by continuous learning and opportunities to learn is a function of degree and type of interactions among organizations. Generally, it determines the rate and extent to which information and knowledge are produced, transferred and utilized. Thus innovative performance of an economy according to Smith (1996) depends not only on how the individual institutions perform on isolation, but also on how they interact with each other as elements of a collective system of knowledge creative and use. A dynamic and progressive interaction results in a great innovation strides. On the contrary, where the system components are compartmentalized and isolated from each other, the result is often that the relevant components are not productive the key characteristics of a system of innovation are therefore not so much its component parts but rather how it performs as a dynamic whole. Adapting the various definitions of innovation system, agriculture innovation system comprised of organizations that jointly or individually deal with issues relating to agriculture, farming, input supply, processing, marketing, research, extension, training, credit, information and policy. The organizations contribute to the development, diffusion and application of new and improved knowledge/technologies and influence the process of change in agriculture. It represents multiplicity of organizations, research institutes, universities, colleges of agriculture, government extension and rural development agencies, private input dealers, agro processors, consultancy firms, farmers and farmers' organization. Outputs from these organizations inform of technical knowledge, farm information/feedback, socio-cultural information and products through interaction and linkages determine the rate of innovation. Ideally, interaction through linkages facilitates exchange of information, skill, knowledge and resources which largely bears on the component output of the whole system. Organizations in the agricultural innovation system have been severally classified in literature. In this study, based on the major functions, roles, mandates and policies, the organizations in the agricultural innovation system have been classified into three major sub-systems: the knowledge/technology generating sub-system, transfer sub-system and utilization lapplication sub-system. Innovation generating sub-system includes research institutes, and training institutions example international and national research institutes, universities, colleges of agriculture, training institutes; while the transfer sub-system include public extension agencies, NGOs/private agencies, processing 
and marketing firms and others. The utilization sub-system consists of farmers, consumers, farmers association. The sub-systems overlap in their functions in the innovation process. In principle, the organizations interact and link at different stages of innovation generation, transfer and application. The performance and strength of the system is a function of the intensity of linkages between and among the components of the sub-systems. On the other hand, interaction both vertically (across the sub-system) and horizontally (within the sub-system) is fundamental and a panacea to cost effectiveness, efficient and optimal resource use among components of the system. In the past, linkage studies in Nigeria have largely focused on improving linkage problems between agricultural research and extension system (Agbamu, 2000, 1999 and 1998). Theoretically a large volume of work has been advanced in literature on improving research -extension -farmer- input linkages; while considerable attention has been directed on research-education and extension linkages (Uzuegbunam 2001, Williams, et al 1990). Specifically, these studies have largely focused on vertical linkages (among organizations across the sub-systems) with less attention on horizontal linkages (linkages among organizations at the same level). Thus empirical data on linkages within and among organizations in the transfersub system are less advanced in literature The study therefore focused on the linkage behavior of the organizations in the transfer sub-system. The questions are; what is the linkage habit of agencies in the agricultural transfer sub-system? Are the organization linked to relevant knowledge sources? What types of linkages exist in the sub-system? What mechanisms are used to forge linkages among agencies in the sub-system? To provide answers to the above questions the study therefore aimed to:

1. describe the types of linkages in the agricultural innovation sub-systems;

2. identify the mechanisms employed for linkages among the agencies;

3. determine impediments to linkage in the sub-system.

\section{METHODOLOGY}

The study was conducted in southeastern agro-ecological Zone of Nigeria. Out of the nine states that made up southeast, three states namely Enugu, Ebonyi and Rivers were purposively selected for the study. This was because of the presence of functional agencies involved in the innovation transfer sub-system. Agencies in the agricultural innovation transfer sub-system existed either as public or private/ NGOs. Agricultural development programmes (ADPs) and local Governments (LGs) were purposively selected to represent the public agencies. ADPs and LGs are the main agencies of government with mandate for extension services. The list of administrative and technical officers in ADPs were accessed and used. All the programme managers (3), director of extension(3),zonal extension officers (18) were used; and subject matter specialists (15) and block extension supervisors (21) purposely selected, were used. A total of 60 respondents were used. The number of local governments in the state was accessed as follows: Enugu (17), Ebonyi (13) and Rivers (23). Ten federal government recognized local government were purposively selected from each state ((30LGs). The head of agriculture and one extension officer from each local government were studied giving a total of 60 respondents from LGs (Table 1). Private/ NGOs agencies existed as either profit NGOs or non-profit NGOs. 
Journal of Agricultural Extension

Vol. 12 (2) December, 2008

TABLE 1: Government/public organizations' sample frame

\begin{tabular}{|c|c|c|c|c|c|c|c|c|c|c|}
\hline \multirow[t]{2}{*}{ State } & \multicolumn{7}{|c|}{ ADPs } & \multicolumn{3}{|c|}{ LGs } \\
\hline & $\begin{array}{l}\mathbf{P} \\
\mathbf{M}\end{array}$ & $\begin{array}{c}\mathrm{DE} \\
\mathrm{S}\end{array}$ & $\begin{array}{l}Z \\
M\end{array}$ & ZEO & $\begin{array}{c}\text { SM } \\
\text { S }\end{array}$ & BES & $\begin{array}{l}\text { Tot } \\
\text { al }\end{array}$ & $\begin{array}{l}\text { Head of } \\
\text { agricultur } \\
\text { al dept. }\end{array}$ & $\begin{array}{l}\text { Agricultur } \\
\text { al officers }\end{array}$ & $\begin{array}{l}\text { Tot } \\
\text { al }\end{array}$ \\
\hline Ebonyi & 1 & 1 & 3 & 3 & 5 & 7 & 20 & 10 & 10 & 20 \\
\hline Rivers & 1 & 1 & 3 & 3 & 5 & 7 & 20 & 10 & 10 & 20 \\
\hline Enugu & 1 & 1 & 3 & 3 & 5 & 7 & 20 & 10 & 10 & 20 \\
\hline Total & 3 & 3 & 9 & 9 & 15 & 21 & 60 & 30 & 30 & 60 \\
\hline
\end{tabular}

Two non-profit NGs were purposively selected based on the level of involvement in services delivery (6NGOs). Specially the non-profit NGOs used were; Rivers Sudan United Mission (SUM), International Institute for Rural Development (IIRD), Enugu: Nsukka United Self Help Organization, (NUSHO) Nigeria Agric Oil Company (NAOC), Shell Petroleum Development Company (SPDC). The head of agriculture and four extension workers purposively selected from each NGOs, giving a total of 30 respondents from non-profit NGOs were studied. The profit NGOs/ private agencies operated in different forms, and were categorized into five: agro-processing and marketing, input/agro-chemical dealers, agro equipment-firms, paraveterinary/livestock enterprise, credit institutions/ support services. Two of each form was selected from each state and a total of 30 profit NGOs were used for the study. The chief executive and one agent purposively selected from each profit NGOs were used for the study. A total of 60 respondents from profit NGOs were studied (Table 2). A total sample size of 210 respondents was used for the study.

TABLE 2: Non-governmental organization sample frame

\begin{tabular}{llcccccc}
\hline & \multicolumn{2}{c}{ Non-profit NGOs } & \multicolumn{4}{c}{ Profit NGOs } \\
\cline { 2 - 7 } Enugu & $\begin{array}{c}\text { Head of } \\
\text { agric/co- } \\
\text { ordinator } \\
\text { for agric }\end{array}$ & $\begin{array}{c}\text { Extension } \\
\text { supervisorl } \\
\text { field agents }\end{array}$ & Total & $\begin{array}{c}\text { Directors/ } \\
\text { chief } \\
\text { executive }\end{array}$ & $\begin{array}{c}\text { Sales } \\
\text { agent/ } \\
\text { public } \\
\text { relation } \\
\text { officers }\end{array}$ & Total \\
Ebonyi & CIDJAP & 1 & 4 & 5 & 10 & 10 & 20 \\
Rivers & SUSHO & 1 & 4 & 5 & & & \\
& IIRD & 1 & 4 & 5 & 10 & 10 & 20 \\
Total & SPDC & 1 & 4 & 5 & & & \\
\hline
\end{tabular}


However, 174 completed questionnaire were found analyzable.

Data were collected with questionnaire. The instrument for data collection was divided into 3 based on the objectives. First section addressed issues on type of linkages with relevant organizations. Respondents were asked to indicate types of linkages using four Linkert type scale of strong,(3) somewhat strong,(2) weak(1) and non-existence(0). The second section elicited information on the type of linkage arrangements. Possible linkage arrangements were listed and the respondents were asked to indicate the one used by their organization. Impediments to linkages in the sub-system were identified. The respondents were asked indicated the perceived linkage impediments on a four point Linkert scale of very great extent (4) great extent (3), little extent (2) very little extent (1). The data were analysed using percentage, and factor analysis.

\section{RESULTS AND DISCUSSION}

\section{Types of Linkages of the Public and NGOs Agencies with Relevant Organizations}

\section{in the Agricultural Innovation System}

Table 3 shows that majority (77.2\%) of ADPs had strong linkage with research institutes (RI), but had weak linkages with NGOs (43.9\%), credit institutions $(45.6 \%)$ processing and manufacturing firms (47.1\%), private input dealers $(38.1 \%)$ LGs $(50.9 \%)$ and consultancy firms (50.9\%). A good proportion $(42.1 \%, 42.1 \%, 42.1 \%$, $50.9 \%$ ) opined that ADPs had somewhat strong linkages with faculties of agriculture (FA), Para-veterinary firms (PVF) input dealers (AID) and farmers organizations (FO), respectively. The findings reveal that ADPs had strong linkage with agricultural technology generating system but weak linkage with most agencies in dissemination sub-system. That means a strong technical base for ADPs, but weak connectivity for efficiency in transferring the same to the client system. The results confirm the observation that the public agencies lack innovation spirit and have been pre-occupied with services delivery (Tugrul et al., 2001).

Table 3 also shows that LG system had no linkage with most agencies both in innovation generation and dissemination system. Majority $(44.4 \%, 46.7 \%, 51.1 \%$, $44.4 \%, 53.3 \%$ ) of LG respondents indicated non-existence of linkages with RI, UA, CA, CF and PMF, respectively. The LGs also had weak linkage with credit institutions $(46.7 \%)$, but a somewhat strong linkage (40.6\%) with the ADP system. The results show that the LG system was characterized by very poor linkage with most of the relevant agencies in the agricultural innovation system. This had no doubt contributed to the gross inefficiency and poor performance of the LG agricultural extension sector. The poor linkage status of the LGs stand as a threat to the 2005 agricultural policy thrust which emphasized devolving extension service to the LGs. Technically, the LG system lacks the capability to implement extension programmes to farmers.

The profit oriented NGOs had poor linkages with most relevant organization in the agricultural innovation system. Data on the table show that $55.2 \%, 52.2 \%, 58.7 \%$, $56.5 \%$, and $58.7 \%$ of profit NGOs had no linkage with RI, UA, CA, FA and $\mathrm{Cl}$, recpectively. The respondents also indicated non-existent of linkage with PVF(43.5\%), and CF(45.6\%). Only about $35 \%, 39 \%$ and $37 \%$ of profit NGOs indicated the existence of weak linkages with UA, Non-profit NGOs and FO, respectively. It is surprising to note that linkages among profit agencies were not very pronounced. 
This could be as a result of competition for survival among the agencies. Also evident from the study, were very weak linkages with other relevant organizations, which invariably impact on the expertise and hence quality of services provided to the farmers. Isife (2000), reported that profit NGOs largely depend on manufacturing firms for technical information.

Furthermore, Table 3 shows that majority $(50.0 \%)$ of non-profit NGOs had somewhat strong linkages with research institutes.About $62 \%, 66 \%$, and $50 \%$ reported non-existence of linkages with UA, CA and PMF, respectively.Also $46.2 \%$ of the respondents reported the existence of weak linkages with FA, while less than $35 \%$ expressed weak linkages with PVF and AID. About $39.5 \%$ and $65.1 \%$ of the respondents opined that non-profit NGOs had quite strong linkages with ADPs and farmer organizations (FO), respectively. The results of the analysis confirm the observations that some NGOs often choose to work alone, because, in their opinion, there is little relevance in the public sector programme for their clientele (Jules and Chamber, 2001).

Besides, non-profit NGOs often ignore the social and political content of the operational environment because of the grassroot mainstreaming employed in development effort. According to Farrington and Bebbington (2000), it is uncommon for NGOs to generate technology which government agencies disseminate but quite common for NGO and NARS (National Agricultural Research System) to conduct research jointly. This perhaps, accounts for the strong linkages between non-profit NGOs and research institutes, and conversely for the weak linkage expressed for other agencies. 
TABLE 3: Percentage distribution of respondents by type of linkages with relevant organization

\begin{tabular}{|c|c|c|c|c|c|c|c|c|c|c|c|c|c|}
\hline Agencies & $\begin{array}{l}\text { RI } \\
\text { (\%) }\end{array}$ & $\begin{array}{l}\text { UA } \\
(\%)\end{array}$ & $\begin{array}{l}\text { CA } \\
\text { (\%) }\end{array}$ & $\begin{array}{l}\text { FA } \\
(\%)\end{array}$ & $\begin{array}{l}\text { PVF } \\
(\%)\end{array}$ & $\begin{array}{c}\text { Non } \\
\text { PNGO } \\
(\%)\end{array}$ & $\begin{array}{l}\text { CI } \\
(\%)\end{array}$ & $\begin{array}{l}\text { CF } \\
(\%)\end{array}$ & $\begin{array}{l}\text { PMF } \\
(\%)\end{array}$ & $\begin{array}{l}\text { FO } \\
(\%)\end{array}$ & $\begin{array}{l}\text { AID } \\
(\%)\end{array}$ & $\begin{array}{l}\text { ADP } \\
(\%)\end{array}$ & $\begin{array}{l}\text { LGs } \\
(\%)\end{array}$ \\
\hline ADPs & - & & & & & & & & & & & & \\
\hline Non-existent & & 12.3 & 17.5 & 5.3 & 17.5 & 19.3 & 15.8 & 19.10 & 10.5 & 1.8 & 8.8 & 0.0 & 10.5 \\
\hline Weak & 3.5 & 15.8 & 31.6 & 22.8 & 33.3 & 43.9 & 45.6 & 50.9 & 47.1 & 10.5 & 38.6 & 10.5 & 50.9 \\
\hline $\begin{array}{l}\text { Somewhat } \\
\text { strong }\end{array}$ & 19.3 & 38.6 & 28.1 & 42.1 & 42.1 & 28.0 & 26.3 & 24.6 & 31.6 & 50.9 & 42.1 & 24.6 & 28.1 \\
\hline $\begin{array}{l}\text { Quite strong } \\
\text { LGs }\end{array}$ & 77.2 & 33.3 & 22.8 & 29.8 & 7.1 & 8.8 & 12.3 & 5.2 & 15.8 & 36.8 & 10.5 & 64.9 & 10.5 \\
\hline Non existent & 44.4 & 46.7 & 51.1 & 37.8 & 33.3 & 33.3 & 33.3 & 44.4 & 53.3 & 26.7 & 35.6 & 13.3 & 26.7 \\
\hline Weak & 17.8 & 24.4 & 17.8 & 28.9 & 20.0 & 31.2 & 46.7 & 44.4 & 35.6 & 22.2 & 28.9 & 11.1 & 8.9 \\
\hline $\begin{array}{l}\text { Somewhat } \\
\text { strong }\end{array}$ & 24.4 & 24.5 & 26.7 & 31.1 & 26.7 & 22.2 & 17.8 & 8.9 & 6.7 & 24.4 & 24.4 & 40.0 & 20.0 \\
\hline $\begin{array}{l}\text { Quite strong } \\
\text { Profit NGOs }\end{array}$ & 13.4 & 4.4 & 4.4 & 2.2 & 20.0 & 13.3 & 2.2 & 2.2 & 4.4 & 26.7 & 11.1 & 35.6 & 44.4 \\
\hline Non existent & 55.2 & 52.2 & 58.7 & 56.5 & 43.5 & 32.6 & 58.7 & 45.6 & 34.8 & 37.0 & 30.4 & 28.3 & 30.4 \\
\hline Weak & 5.2 & 35.4 & 28.3 & 17.4 & 6.5 & 39.1 & 26.1 & 17.4 & 21.7 & 37.0 & 21.7 & 28.3 & 34.8 \\
\hline $\begin{array}{l}\text { Somewhat } \\
\text { strong }\end{array}$ & 19.6 & 8.7 & 6.5 & 15.2 & 21.7 & 10.9 & 8.7 & 26.1 & 17.4 & 15.2 & 19.6 & 21.7 & 26.1 \\
\hline $\begin{array}{l}\text { Quite strong } \\
\text { Non profit } \\
\text { NGOs }\end{array}$ & 13.0 & 8.7 & 6.5 & 10.9 & 28.3 & 17.4 & 6.5 & 10.9 & 6.1 & 10.8 & 28.3 & 21.7 & 8.7 \\
\hline Non existent & 11.5 & 61.6 & 65.5 & 26.9 & 30.8 & 23.6 & 30.8 & 38.5 & 50.0 & 15.4 & 38.5 & 11.5 & 15.4 \\
\hline Weak & 15.4 & 19.2 & 11.5 & 46.2 & 34.6 & 33.3 & 3.5 & 11.5 & 30.8 & 7.7 & 34.6 & 19.2 & 38.5 \\
\hline $\begin{array}{l}\text { Somewhat } \\
\text { strong }\end{array}$ & 50.0 & 3.8 & 19.2 & 15.4 & 23.1 & 24.7 & 34.6 & 34.6 & 7.7 & 11.5 & 19.2 & 30.8 & 38.5 \\
\hline Quite strong & 23.1 & 15.4 & 3.8 & 11.5 & 11.5 & 18.4 & 30.8 & 15.4 & 11.5 & 65.4 & 7.7 & 38.5 & 7.7 \\
\hline
\end{tabular}

* $R I=$ Research institutes

$U A=$ University of agriculture

$C A=$ Colleges of agriculture

$F A=$ Faculties of agriculture

$P V F=$ Para veterinary firms

NPNGO = Non profit NGOs

$\mathrm{Cl}=$ Credit institutions

$\mathrm{CF}=$ Consultancy firms

$P M F=$ Processing and marketing firms

$F O=$ Farmer organizations

$A I D=$ Agro input dealers

ADPs = Agricultural Development Programmes

$L G=$ Local Government

\section{Linkage Arrangement Among Agencies in the Agricultural Innovation Transfer sub-System}

Linkage arrangement between the public agencies (ADPs and LGs)

The data in Table 4 show the linkage arrangement existing between ADP and LG extension systems. Majority (61.4\%) of the ADPs' respondents indicated that ADPs' had informal interactions with LGs, while only about $37.8 \%$ of LG respondents perceived the existence of informal linkage between the agencies. A greater proportion (57.8\%) of LGs respondents reported that the staff of ADP and LG had free access to annual reports, bulletin, and newsletter, while about $38.0 \%$ of ADPs' respondents shared the same view. Less than $2 \%$ of ADPs' and $2.2 \%$ of LGs respondents indicated the existence of joint funding of projects. A very low perception was also reported by ADPs' respondents for joint budgeting and policy formulation (3.5\%), and exchange of personnel (5.3\%). Also $33.0 \%$ of LGs and $17.5 \%$ of ADP respondents opined to the existence of joint use of resource persons at workshops, 
seminars and conferences. A lesser percentage $7.0 \%, 17.5 \%, 12.3 \%, 14.0 \%, 10.5 \%$ of ADPs respondents reported that ADPs and LGs shared physical facilities, joint diagnoses of field problems, had joint planning and evaluation of programme, joint training of extension workers and joint use of supervisors, respectively. The LGs' respondents on the other hand, expressed similar view to other linkage arrangements. The results showed that ADPs and LGs had mainly informal linkages. Annual reports and newsletter employed may not be adequate to enhance synergies and complementarily in functions of the agencies. Besides, production of annual report and newsletter may not be very regular because of poor funding of programmes. Formal linkage is yet to be operationalized between the two agencies. This may be as a result of rival attitude of the agencies to one another.

TABLE 4: Percentage distribution of respondents by linkage arrangement between ADPs and LGs

\begin{tabular}{lcc}
\hline Linkage arrangement & $\begin{array}{c}\text { ADP } \\
\text { (n= } \mathbf{5 7}) \\
(\mathbf{\%})\end{array}$ & $\begin{array}{c}\text { LG } \\
\mathbf{( n = 4 5 )} \\
(\mathbf{\%})\end{array}$ \\
\hline $\begin{array}{l}\text { Personnel of both agencies have free access to } \\
\text { annual reports bulletin, farm magazine }\end{array}$ & 38.6 & 57.8 \\
ADP and LG share physical facilities e.g. audio- & 7.0 & 4.4 \\
visuals, mobile van. & & \\
Joint diagnosis of field problems & 17.5 & 8.9 \\
Have joint planning and evaluation of programme & 12.3 & 11.1 \\
Have joint funding of projects & 1.8 & 2.2 \\
Have joint training of extension workers & 14.0 & 24.4 \\
Informal interaction among staff & 61.4 & 37.8 \\
Joint use of supervisors & 10.5 & 11.1 \\
Joint use of resource persons at workshops, \& & 17.5 & 33.3 \\
seminars. & & \\
Joint budgeting \& policy formulation & 3.5 & - \\
Exchange of personnel & 5.3 & 6.7 \\
Joint formation and use of farmer groups. & 28.1 & 37.8 \\
\hline
\end{tabular}

*Multiple responses

\section{Linkage arrangement between the public and NGOs agencies}

Responses on linkage arrangement between the public and the NGOs agencies as perceived by the extension workers of the agencies in the agricultural innovation system were sought as follows: 
Linkage arrangement between the public and NGOs agencies as perceived by public agencies

Table 5 shows response of the public sector agencies (ADPs and LGs) to linkage arrangements with NGOs (profit and non profit). The table shows that $49.1 \%$ and $43.9 \%$ ADPs' respondents expressed the existence of informal linkage with the non-profit NGOs and profit NGOs respectively. About 39\% of ADPs respondents indicated that they had free access to annual reports, bulletin, and farm magazine of non-profit NGOs, while only $19.3 \%$ expressed the same for profit NGOs. Nearly $32 \%$ and $30 \%$ of ADPs respondents indicated that ADPs sent their clients for consultation to profit and non profit NGOs respectively. Joint community mobilization $(21.1 \%$ and $10.5 \%)$, joint diagnosis of farm problems (17.5\% and $19.3 \%)$ joint funding of training and projects (15.8\% and $8.8 \%$ ) were not much used by ADPs as linkage mechanisms to non-profit and profit NGOs respectively.

In the same vein, LGs had informal linkage (46.7\%, 48.9\%) with non-profit and profit NGOs, respectively. About $40 \%$ LGs respondents indicated linkage to non-profit NGOs by free access to bulletin, farm magazine and annual reports, while only $2.2 \%$ of LGs respondents reported the existence of linkage to profit NGOs by the same arrangement. Majority (48.9\%) of LGs respondents said that profit NGOs supply input to them, while about $31 \%$ indicated the existent of joint community mobilization with non-profit extension agencies. However, only $2.2 \%$ expressed linkage by free access to bulletin, annual reports and joint community mobilization between LG and profit NGOs. It can be deduced from the findings that the most common linkage arrangement as perceived by ADPs and LGs extension staff were informal interaction and free access of staff of the agencies to annual reports, farm magazine and bulletin. The more operational linkage arrangements were rarely used. This shows poor innovation spirit, which may have immensely contributed to the low performance of the public system.

TABLE 5: Percentage distribution of public sector respondents by linkage arrangement with NGOs

\begin{tabular}{|c|c|c|c|c|}
\hline \multirow[b]{2}{*}{ Linkage arrangements } & \multicolumn{2}{|c|}{ ADPs (n = 57) } & \multicolumn{2}{|c|}{ LGs (n = 45) } \\
\hline & $\begin{array}{c}\text { Non } \\
\text { profit } \\
(\%)\end{array}$ & $\begin{array}{c}\text { Profit } \\
\text { NGOs } \\
(\%)\end{array}$ & $\begin{array}{c}\text { Non } \\
\text { profit } \\
\text { NGOs } \\
(\%)\end{array}$ & $\begin{array}{c}\text { Profit } \\
\text { NGOs } \\
(\%)\end{array}$ \\
\hline Informal linkage/interaction & 49.1 & 43.9 & 46.7 & 48.9 \\
\hline $\begin{array}{l}\text { Joint funding of training programme and } \\
\text { projects }\end{array}$ & 15.8 & 8.8 & 15.6 & 4.4 \\
\hline Joint diagnosis of farm problems & 17.5 & 14.0 & 2.2 & 24.4 \\
\hline $\begin{array}{l}\text { aree access to oulletin rarm magazine, } \\
\text { annual reports }\end{array}$ & 38.6 & 19.3 & 40.1 & 2.2 \\
\hline Share technical information & 21.1 & 10.5 & 11.1 & 15.6 \\
\hline ADP/LG send clients for consultation & 31.6 & 29.8 & 24.4 & 11.1 \\
\hline NGOs supply inputs / equipment & 17.5 & 26.3 & 6.7 & 48.9 \\
\hline Joint community mobilization & 24.6 & 3.6 & 31.1 & 2.2 \\
\hline Have joint annual workshop & 24.6 & 14.0 & 28.9 & 8.9 \\
\hline
\end{tabular}

*Multiple responses 
Linkage arrangement between public and NGOs agencies as perceived by NGOs

Table 6 shows linkage arrangements between public and NGOs extension organizations as perceived by NGOs respondents. Majority $(54.3 \%)$ of the profit NGOs indicated the presence of informal linkage with ADPs, while $39.1 \%$ expressed the same view for LGs extension system. About 30\% (profit NGOs) respondents reported that they shared bulletin and farm magazine with ADPs and $6.5 \%$ with LGs. More than $30 \%$ of profit NGOs opined that ADP sends client for consultation, while $19.6 \%$ indicated the same for LGs. Only $6.5 \%$ of profit NGOs agreed to the existence of joint funding of training and projects with ADPs. Similarly other linkage arrangements were not much used by profit NGOs.

Table 6 further indicates that majority $(42.3 \%)$ of non-profit NGOs reported the existence of informal interaction with staff of the ADPs, while $19.2 \%$ indicated the same interaction with LGs. Also (46.3\%) of the respondents of non-profit NGOs indicated that the agencies shared bulletin, farm magazine, and annual reports with ADPs, while $11.5 \%$ indicated that they shared with LGs through the same mechanism. About $38.5 \%$ indicated linkage by joint annual workshop/seminars between non-profit NGOs and ADP and $33.3 \%$ with LGs system. The result shows that respondents of both profit and non-profit NGOs indicated very low perception to linkage arrangement with LGs extension system, while ADPs extension system are relatively more linked with profit and non-profit NGOs. But generally, informal interaction and free access to bulletin, farm magazine and annual reports were the most common linkage arrangement adopted. Structural and more operational linkage mechanisms were not very common among the agencies. The linkage arrangements identified are inadequate to optimised agency's distinctive goal under agency's specific constraints and component constraints. According to Clay and Shaffer (1984) linkages and networks among actors and organization in the same area underline the effectiveness of both NGOs and development intervention.

TABLE 6: Percentage distribution of NGOs/private respondents by linkage arrangement with ADPs and LGs

\begin{tabular}{|c|c|c|c|c|}
\hline \multirow[t]{2}{*}{ Linkage arrangement } & \multicolumn{2}{|c|}{$\begin{array}{c}\text { Profit NGOs } \\
n=46(\%)\end{array}$} & \multicolumn{2}{|c|}{$\begin{array}{c}\text { Non profit } \\
\text { NGOs } \\
n=26(\%)\end{array}$} \\
\hline & ADPs & LGs & ADPs & LGs \\
\hline Informal linkages/interaction & 54.3 & 39.1 & 42.3 & 19.2 \\
\hline Joint funding of training and projects & 6.5 & 0.0 & 7.7 & - \\
\hline Joint diagnosis of farm problems & 17.4 & 4.3 & 11.5 & 3.8 \\
\hline $\begin{array}{l}\text { Free access to bulletin, Farm magazine and } \\
\text { annual reports }\end{array}$ & 30.4 & 6.5 & 46.2 & 11.5 \\
\hline Private agencies supply input/equipment/tools & 13.0 & 8.7 & 15.4 & 11.5 \\
\hline ADP/LG send clients for consultation & 30.4 & 19.6 & 26.9 & 23.1 \\
\hline Joint community mobilization & 13.0 & 13.0 & 19.2 & 15.4 \\
\hline Have joint annual workshops and seminars & 23.9 & 13.0 & 38.5 & 11.5 \\
\hline
\end{tabular}

${ }^{*}$ Multiple responses 
Linkage arrangement between NGOs (profit NGO and non profit NGOs) extension organisations

Table 7 shows that majority $(65.4 \%)$ of non profit NGOs shared information with profit NGOs through bulletin, farm magazine, and annual reports, while $23.9 \%$ of profit NGO reported the existence of the same linkage arrangement with non-profit NGOs. About $30.4 \%$ of profit NGO and $69.2 \%$ of non-profit NGOs respondents indicated that they both have joint annual workshops and seminar. The response here could be as a result of pockets of workshops organized by profit NGOs especially when innovations or products are being introduced to the client system via service agencies. Only about $37 \%$ of profit NGOs and $26.9 \%$ of non profit NGOs indicated the existence of informal interaction with one another. Linkage arrangements by supply of inputs, equipment and tools were less used by both agencies. The results show that free access to bulletin, farm magazines and annual workshops seem to be the most common channel of interaction between profit and non-profit NGOs. The linkage arrangement identified by the respondents could be possible because it underpins the profit oriented goal of the profit NGOs. Such arrangements help the profit NGOs to advertise and market their products.

TABLE7: Percentage distribution of Respondents by linkage arrangement between profit and non-profit NGOs

\begin{tabular}{lcc}
\hline \multicolumn{1}{c}{ Linkage arrangement } & $\begin{array}{c}\text { Profit } \\
\text { NGOs } \\
(\mathbf{n = 4 6 )} \\
(\mathbf{\%})\end{array}$ & $\begin{array}{c}\text { Non profit } \\
\text { NGOs } \\
(\mathbf{n = 2 6 )} \\
(\mathbf{\%})\end{array}$ \\
\hline Have informal linkage & 37.0 & 26.9 \\
Profit NGOs supply inputs, equipment and tools & 15.2 & 11.5 \\
Profit/non profit NGOs share information through free & 23.9 & 65.4 \\
access to bulletin magazine annual reports. & & \\
$\begin{array}{l}\text { Share physical infrastructure (mobile van, audio } \\
\text { visuals) }\end{array}$ & 6.5 & 11.5 \\
Joint training of staff & 13.0 & 6.4 \\
Have joint funding of programmes / training & 2.2 & 23.1 \\
Have joint annual workshop/seminars & 30.4 & 69.2 \\
\hline
\end{tabular}

\section{Factor Analysis on Linkage Constraining Factors}

Table 8 show varimax rotated factor matrix on linkage constraining factors. Based on variable loading, four factors were identified and named. Factor one was named political and/or policy related constraints, which include pressure from policy and its effect on values, reward and sanctions. Factors that loaded high under political /policy related constraints were poor access to knowledge and information on new technologies (.70), inappropriate government policy (.65), limited human resource in the agencies for linkage leadership (0.64) poor government commitment to extension (0.60), low mobility of expert (0.51), limited physical resources (0.48), and inequality Igap in qualification and salary scale (0.46). Government policies are indispensable in 


\section{Journal of Agricultural Extension \\ Vol. 12 (2) December, 2008}

determining research priorities, human resource quality and quantity and interrelationship between agencies. Some policies limit flexibility that agencies need to be responsive to each other and may increase competition instead of cooperation. For instance, the structural adjustment policies being implemented across the globe, with its characteristic budget cutbacks on public services, have greatly affected the public sector efficiency in generating, accessing and disseminating technologies, building adequate qualified manpower resource; infrastructural facilities, among others. This agrees with the findings that linkage system in Nigeria is characterize by problems such as inappropriate research policy and institutional arrangement for linkage, poor quality personnel and decision making methods; conditions at on farm levels trials and inadequate finance (Agbamu, 1999). Also reporting on research - extension system, Williams et al (1990) observed that variables limiting effectiveness of linkage were differences in recruitment policies, conflicts between extension workers and researchers in the choice of research priorities, location of different ministries and reliance on technical solution to agricultural problems. Above all, he observed that research extension typology in Nigeria shows unequal status among agencies and top-down decision making procedure.

Factor 2 was named organizational/ institutional constraints. Issues identified here include weak legal framework (0.74) organizational rigidities (0.20), excessive organizational fragmentation (0.63) long administrative procedure (0.53) and overlapping mandates / objectives (0.35) and poor macro system linkage. (0.71), institutional arrangement in which a national research institute sees to the research needs of 6-8 states in an ecological zone is a disincentives to both vertical and horizontal linkages. Also organizational constraints result from unclear delineation of functions, multiplicity of organization with varying ideologies, management policies and bureaucratic bottleneck.

Factor 3 was named attitude related factors. Constraining factors related to attitude include lack of farmers' interest, (0.61) public good characteristics of most extension information (0.64) poor attitude and low morale of extension workers (0.52), poor and / or differences in orientation of personnel of the agencies (0.45) and influence of international mandates. (0.75). Farmers' attitude to extension is determined by level of adoption and degree of involvement in programmes. The participation of private sector agencies in extension has been low probably because of the public good characteristics of extension information. 
Journal of Agricultural Extension

Vol. 12 (2) December, 2008

TABLE 8: Varimax rotated matrix on linkage constraining factors

Constraints variables

Overlapping mandates/objectives

Limited qualified human resources in the agencies for linkage leadership

Lack of adequate sources of finance

Limited physical resources (ICT,

Telephone)

Poor access to knowledge and

information on new technologies

Low mobility of experts/professionals

Poor logistic support and incentive for

linkage.

Organizational rigidities

Long administrative procedure/

administrative bottleneck associated with

public agencies.

Weak legal framework/lack of rule for

interaction/linkage

Poor macro system linkages

Excessive organizational fragmentation

Inappropriate government policy in

agriculture

Poor/differences in orientation of

personnel of the agencies

Influence of international/ donors

mandates

Lack of farmer's interest in extension

Inequality in qualification and salary scale

of staff of the agencies

General poor attitude and low morale of

extension workers.

Poor training opportunities for

professionals

Traditional public characteristics of most

extension information

Poor government commitment to

extension

\section{Factor 1 \\ Political/ policy}

0.32

0.64

0.40

0.48

0.70

0.51

0.39

.100

$-0.06$

0.20

0.17

0.19

0.65

0.36

0.75

0.40

0.46

0.27

0.16

$-0.03$

0.60

Factor 2
Organizational/
institutional

0.35

0.01

$-0.08$

0.19

0.02

0.19

0.18

.704

0.53

0.74

0.71

0.63

0.31

0.39

0.09

0.24

0.27

$-0.00$

0.15

0.37

0.37
Factor 3

Attitude

related

0.26

0.34

0.11

0.02

0.07

0.26

0.06

.206

0.31

0.02

0.18

0.17

0.15

0.45

0.75

0.61

0.39

0.52

0.22

0.40

0.76

0.21

0.17

0.27

0.31

0.63

0.20

0.52

0.20

0.03

0.14

0.05

0.15

0.12

0.05

0.09

0.64

$-0.07$
0.17

32

32




\section{Journal of Agricultural Extension}

Vol. 12 (2) December, 2008

\section{CONCLUSION}

Results of the study reveal poor innovation culture among the agencies in the transfer sub-system. Only ADPs (72.2\%) and non profit NGOs indicated strong linkages with research institutes, but linkages with agencies in the transfer sub-system were either weak or not in existent. Also the LGS as well as profit NGOs agencies had either weak or had no linkage with agencies in the agricultural innovation generating and transfer system. Undoubtedly this might have largely contributed to the inefficiency and ineffectiveness widely reported among policy makers. The results suggest that the agencies operated in isolation, hence the poor linkage behaviour. In addition the major linkage arrangement were use of bulletin, annual reports and magazine which are inadequate for enhanced access to new knowledge, articulation of the demand for research, improved synergy and complementarily in achieving common goals. The respondents perceive that information, knowledge and resources being essence for linkages were constrained by policy, organization, attitude related and motivational factors. The study thus concludes that extension system should be re-oriented toward innovation culture of interaction, information and knowledge flow and resource exchange to innovative strength, consensus and explore opportunities for individual and collective performance. Government and policy makers should entrench linkage mandates in policies establishing extension systems and strategies for enhancing private sector participation in knowledge transfer. Policy makers and extension administrators should facilitate orientation and training for building linkage leadership among stakeholders. Above all, institutional framework supported by legislative guidelines are essential to facilitate linkages at different levels particularly with the private sector.

\section{References}

Agbamu J.U. (1998) A study on agricultural research-extension linkages with focus on Nigeria and Japan. Ph. D Thesis, Tokyo University of Agriculture, Tokyo, Japan: 418.

Agbamu J.U. (1999) The Linkages between agricultural research extension systems: An international perspective, agricultural research and extension network paper; No 106, ODI London, UK: 7.

Agbamu J.U. (2000) Agricultural research extension systems: An international perspective, agricultural research and extension network paper; No 106, ODI London, UK:7.

Clark, N; A. Hall; R. Sulaimain and G. Naik (2003) Research as capacity building: The case of an NGO facilitated post-harvest innovation system for the Himalayan Hills. World Development 31, 11:1845-1863.

Clay, E.J. and B. Schaffer (eds) (1984) Room for Management: An Exploration of Public Policy in Agriculture and Rural Development, London, Heinmann.

Ekboir, L. (2002) (ed). World Wheat Overview and Outlook Developing: No-till Packages For Small-scale Farmers. CIMMYT 2000-2001, Mexico CIMMTY. 
Farrington, J and A.J. Bebbington (2000) From research to innovation: getting the most from interaction with NGOS. In: Scoones, lan and J. Thompson (eds) Beyond Farmer First. London UK: Intermediate Technology Publications, 203-211.

Food and Agriculture Organization FAO (1996) The State of Food and Agriculture 1994. Rome, FAO of the United Nation.

Hall, A., G. Beckett, G. Taylor, M.V. K. Sivamahan, and N. Clark (2001) Why research partnership really matters: Innovation theory, institutional arrangements and implications for developing new technology for the poor. World Development vol, 29 (5): 783-98.

Isife, B.I. (2000) An Analysis of non-government extention systems in southeastern, Nigeria. Ph.D thesis. Department of Agricultural Extension University of Nigeria, Nsukka. Nigeria: 20-90.

Jules,N.P and R. Chambers(2000) Towards a learning paradigm;In:Scoones lan and J.Thompsom (eds) Beyond Farmer First. London UK.Intermediate technology publication:182-202

Nigel, G; A Pyka and P. Ahrweilker (2001) Innovation networks - A simulation approach. Journal of Artificial Societies and Social Simulation 4:3.

Smith, k. (1996) The Norwegian national innovation system: A pilot of knowledge creation. STEP Report OSLO.

The Technical Center for Agricultural and Rural Cooperation(CTA) (2003)ICTs transforming agricultural extention. CTA Observatory WIC/CTA Wageningen, The Netherlands.

Trugul,T. J.Willem, and F.Karimov (2001)The agricultural innovation system of Azerbaijan;functions,linkages, and constaints. Discussion paper.

Tugrul T and M. Ajit (2002) The cotton supply chain in Azerbaijan, ISNAR, the Hague, Netherlands: 13-17.

Uzuegbunam, C.O. (2001) Analysis of linkage between agricultural development programmes and universities in Southeastern Nigeria. Ph.D Thesis. Department of Agricultural Extension, University of Nigeria, Nsukka, Nigeria: 20-50.

Watts, J. R. Mackay, D. Horton; A. Hall; B Douthwaite; R. Xhambers; and Acosta (2003) Institutional learning and change: An introduction; Discussion paper ISNAR. The Netherlands.

Williams, S.K.T; C.E. Williams and G.A. Akinola (1990) Linkage of agricultural research-training-extension systems in agricultural development: the state of that art Nigeria: The Nigeria Journal of Agricultural extension vol. 5: (1 and 2): 48-58. 